\title{
From the Body to the Melody: "Relearning" the Experience of Time in the Later Merleau-Ponty
}

\author{
Jessica Wiskus \\ Aarhus Institute of Advanced Studies; \\ Duquesne University in Pittsburgh, PA \\ jwiskus@aias.au.dk,wiskus@duq.edu
}

Received 31 January 2018; accepted 18 May 2018; published 30 September 2018.

\begin{abstract}
If, as Maurice Merleau-Ponty writes, "True philosophy consists in relearning to look at the world," and if Merleau-Ponty is accordingly often described as a philosopher of the body or a philosopher of painting, how are we to understand the apparently new turn to music that Merleau-Ponty makes toward the end of the final completed chapter, entitled "The Intertwining-The Chiasm," of The Visible and the Invisible?

I argue that the course of the "Chiasm" chapter moves from a concern for the reciprocal intertwining of body and world to a concern for the Ineinander of temporality. Thus, there are two dimensions involved in forming Merleau-Ponty's chiastic structure of the flesh: the fecundity of the sensible world in the dimension of simultaneity and the transcendence of the subject in the dimension of succession.

The aim of this article is to explore the part of this structure that pertains to the temporal movement of transcendental intersubjectivity. Focusing on Merleau-Ponty's adaptation of Husserl's term, Ineinander, I trace the musical context of the term from Merleau-Ponty's course notes, "Philosophie aujourd'hui" to the final passages from the "Chiasm" chapter of The Visible and the Invisible, understanding the Ineinander as it pertains to the relation of past and present. Contrary to the overflowing sense of presence experienced by the body in the world, the Ineinander is characterized by succession - by the écart - and finds its natural expression in the movement of music. Thus, the chiastic structure at the heart of Merleau-Ponty's philosophy of the flesh expresses not only the immersion of a body in the world that sees; it expresses also, as that which is no longer and that which is to come, a creative, melodic movement of time.
\end{abstract}

Keywords: Chiasm; flesh; Husserl; Ineinander; Merleau-Ponty; music; temporality; transcendental intersubjectivity. 
What an abyss of uncertainty, whenever the mind feels overtaken by itself; when it, the seeker, is at the same time the dark region through which it must go seeking and where all its equipment will avail it nothing. Seek? More than that: create. It is face to face with something which does not yet exist, to which it alone can give reality and substance, which it alone can bring into the light of day. (Marcel Proust, Remembrance of Things Past)

Maurice Merleau-Ponty is often lauded for his pioneering effort to think through the relationship between embodiment and perception. ${ }^{*}$ Indeed, throughout his work, MerleauPonty asks us to attend reconsider this relation and how we believe that "the world is what we see" (Merleau-Ponty 1968, p. 3). Phenomenology, in this sense, is taken up as the discipline or practice of a particular kind of seeing. "True philosophy consists in relearning to look at the world," writes Merleau-Ponty in the preface to Phenomenology of Perception - a motto to which he remains faithful throughout his career (1981, p. xxiii). For this relearning reveals that, in our very looking at the world, we are not minds who contemplate from afar-not eternal, all-seeing eyes that would be without body or specific point of view. "Space," he writes, "is no longer a medium of simultaneous objects capable of being apprehended by an absolute observer who is equally close to them all, a medium without point of view, without body and without spatial position - in sum, the medium of pure intellect" (2008, p. 41). Rather, our body, far from being a source of limitation, figures the very opening to the world. We are of the world, he insists. "The thickness of the body, far from rivaling that of the world, is on the contrary the sole means I have to go unto the heart of the things" (1968, p. 135). Our hands that reach out to grasp what seems outside of us are themselves touched; our seeing of what is there, before us, is itself seenis itself immersed in the visible. There is an intertwining between our senses and the world that they display. It is not that the world is spread before us, at a certain distance, about which we make certain calculations or representations; beneath all theorizing - all attempt to fix within an intellectual system - lies the sensuous world of which we are. "Quality, light, color, depth, which are there before us, are there only because they awaken an echo in our bodies and because the body welcomes them" (1993, p. 125).

Thus we may understand how Merleau-Ponty is, today, often described-interchangeably - as a philosopher of the body or philosopher of painting, for the two identities are related. "The painter 'takes his body with him'," quotes Merleau-Ponty in "Eye and Mind," an essay completed in 1960 whose title articulates a relation between the organ of vision and the visibility it offers (1993, p. 123). In an important passage from The Visible and the Invisible - a manuscript drafted from 1959 until the time of his death in 1961Merleau-Ponty explains:

The visible can thus fill me and occupy me only because I who see it do not see it from the depths of nothingness, but from the midst of itself; I the seer am also visible. What makes the weight, the thickness, the flesh of each color, of each sound, of each tactile texture, of

\footnotetext{
* This essay was composed while I served as a Fellow at the Aarhus Institute of Advanced Studies in Aarhus, Denmark. I gratefully acknowledge funding through the AIAS-COFUND Fellowship Programme under grant agreement number 609033 of the European Union's Seventh Framework Programme and Aarhus Universitets Forskningsfond in support of the research that produced this article.
} 
the present, and of the world is the fact that he who grasps them feels himself emerge from them by a sort of coiling up or redoubling, fundamentally homogeneous with them; he feels that he is the sensible itself coming to itself and that in return the sensible is in his eyes as it were his double or an extension of his own flesh. (1968, p. 113-114)

It is, for Merleau-Ponty, the work of the painter who attends so faithfully to this intertwining between body and world; it is the painter who, through the response of his or her gestures to the world, cultivates a discipline of seeing that, like the philosopher, seeks what is there - the "flesh," as he says, "of the present" - but ordinarily obscured or hidden from view. As Merleau-Ponty writes in "Eye and Mind":

Inevitably the roles between the painter and the visible switch. That is why so many painters have said that things look at them. As André Marchand says, after Klee: "In a forest, I have felt many times over that it was not I who looked at the forest. Some days I felt that the trees were looking at me." (1993, p. 129)

Thus, we find that, what was in Phenomenology of Perception forwarded as a proposalthat "true philosophy consists in relearning to look at the world"-in his later works (like "Eye and Mind" and The Visible and the Invisible) is not only confirmed but celebrated. Moreover, Merleau-Ponty's later analysis of this philosophical seeing casts it in terms of a specific kind of temporal presence: as a "depth" of the world that "is pre-eminently the dimension of the simultaneous" (1968, p. 219). Indeed, in much of Merleau-Ponty's late work do we find confession to an expressive overflow of the fullness of the present. For example, in framing the intention of his work on The Visible and the Invisible, MerleauPonty writes:

We shall render explicit the cohesion of time, of space, of space and time, the "simultaneity" of their parts (literal simultaneity in space, simultaneity in the figurative sense in time) and the intertwining (entrelacs) of space and time. And we shall render explicit the cohesion of the obverse and the reverse of my body which is responsible for the fact that my bodywhich is visible, tangible like a thing - acquires this view upon itself, this contact with itself, where it doubles itself up, unifies itself, in such a way that the objective body and the phenomenal body turn about one another or encroach upon one another. (1968, p. 117)

This passage from The Visible and the Invisible confirms the approach to time through space that Merleau-Ponty had developed in Phenomenology of Perception. Here, it is the body that stands at the center of time-consciousness. As he explains in that work: "In every focusing movement my body unites present, past and future, it secretes time, or rather it becomes that location in nature where, for the first time, events, instead of pushing each other into the realm of being, project round the present a double horizon of past and future and acquire a historical orientation" (1981, pp. 278-279). This "double horizon of past and future" envelops the present body: "My body takes possession of time; it brings into existence a past and a future for a present," he continues (1981, p. 279). That is to say, through the body, past and future are held together - intertwined - with the present. As he clarifies, "The lived present holds a past and a future within its thickness" (1981, p. 321). Thus, what Merleau-Ponty develops here is a sense in which past, future, and present are simultaneous. 
It is this thinking of the body, then, that supplies Merleau-Ponty with a vocabulary of metaphors that he employs even in his late work. Thus, in particular, the first half of the final completed chapter of The Visible and the Invisible, entitled "The Intertwining-The Chiasm," invokes terms like overlapping, reversibility, encroachment, intertwining, doubling up, coiling over and pregnancy with a repetitive insistence that makes almost an incantation: we, through this writing, have a sense of immersion within a total vision - a "coiling up" of vision and visibility that Merleau-Ponty had already outlined, in "Eye and Mind," as the theme of painter and, as we have seen, his motto for the true philosophy.

Where does this performance lead? That is to say, how are we to understand the apparently new - and impassioned - turn to music that Merleau-Ponty makes toward the end of this "Chiasm" chapter? For hasn't this chiasm already been figured by Merleau-Ponty as the intertwining of vision and visibility — realms of perception that are quite far from the musical experience? Indeed, it is in "Eye and Mind" that Merleau-Ponty explores the expressions of painters as that which accords with his own philosophical thinking, and it is no accident that, in this very essay, Merleau-Ponty claims that music "is too far on the hither side of the world and the designatable to depict anything but certain schemata of Beingits ebb and flow, its growth, its upheavals, its turbulence" (1993, p. 123). After all, musical expression does not partake of the visible; it does not seem to see us any more than we see it. Should we not, then, take this as confirmation of the decisive significance that painting must play in our interpretation of Merleau-Ponty's work, even up through the course notes and incomplete drafts? Yet - and we must underline this, for the omission is striking - the name of Cézanne does not appear on the pages of The Visible and the Invisible; rather, we have Proust and Claudel - writers singularly inspired by music. But why music? What is it that painting alone cannot show us? The way that Merleau-Ponty's own prose sings through the fourth chapter of The Visible and the Invisible indicates that it is not simply that Merleau-Ponty chooses Proust's petite phrase as one of many different possible tropes to develop. Following Proust and Claudel, it seems that suddenly for Merleau-Ponty, music itself, as an expression, inspires his own philosophical creativity. ${ }^{1}$ As Claudel writes, "To be is to create. All things living in time listen, concert, and compose" (1948, p. 27). This listening, performing and composing is what works its way through the rhapsodic passages penned by Merleau-Ponty in the final pages of the "Chiasm" chapter. Here, MerleauPonty's voice speaks perhaps less like a member of the academy and more like a poetmusician. Proust helps us understand the significance of such a shift in tone when he writes,

This music seemed to me something truer than all known books. At moments I thought that this was due to the fact that, what we feel about life not being felt in the form of ideas, its literary, that is to say intellectual expression describes it, explains it, analyses it, but does not recompose it as does music, in which the sounds seem to follow the very movement of our being. (Proust, 1981, p. 381)

\footnotetext{
${ }^{1}$ For readings of this petite phrase of Proust in terms of the full context of the "sensible idea" - a notion that Merleau-Ponty develops in the "Chiasm" chapter of The Visible and the Invisible, please see chapter 8, "On the Musical Idea of Proust" of my book, The Rhythm of Thought (2013) and chapter 4, "The Thinking of the Sensible," of Carbone's The Thinking of the Sensible (2004).
} 
The performance, then, or recomposition of philosophical thought, is the expressive activity of precisely our being in its movement through time, i.e. our subjectivity. It is with this sensitivity to the creative capacity of the subject that Merleau-Ponty writes, quoting Proust, that music "give[s] us the assurance that the 'great unpenetrated and discouraging night of our soul' is not empty, is not nothingness" (1968, p. 150).

We might say, in sum, that the course of development traced in Merleau-Ponty's "Chiasm" chapter turns from a concern for the reciprocal and simultaneous intertwining of body and world to a concern for the successive Ineinander of temporality. "To begin with," he writes at a turning point of that chapter, "we spoke summarily of a reversibility of the seeing and the visible, of the touching and the touched. It is time to emphasize that it is a reversibility always imminent and never realized in fact" (1968, p. 147). This slippage calls our attention to the role that succession plays in our intercourse with the world. That is to say, the figure of the "chiasm" invokes an other dimension pertaining to the body - a dimension of time - thereby bringing to life his philosophy of the flesh. This is a dimension according to which the subject is not present to herself but experiences an "incessant escaping" (1968, p. 148); here we have, in place of the intertwining, the écart.

Thus, there are two dimensions that we must understand as involved in forming MerleauPonty's chiastic structure of the flesh: the fecundity of the sensible world in the dimension of simultaneity and the transcendence of the subject in the dimension of succession. Experience emerges as "a certain node in the woof of the simultaneous and the successive" (1968, p. 132). An interpretation of Merleau-Ponty's work that draws solely upon the first dimension - insofar as it constructs a philosophy of the body - fails to take into account the overall movement of thought operative in the "Chiasm" chapter of The Visible and the Invisible. On the contrary, my aim is to disclose the depth of the "flesh" that Merleau-Ponty develops in his very last work by attending to the subtle way in which Merleau-Ponty's thinking about time changes, culminating in his engagement with the petite phrase of Proust.

Although imperfectly developed in the writings left unfinished at the time of his death, the thinking of this chiastic structure of which the flesh is a part is sketched out not only in The Visible and the Invisible but also in lecture notes for the courses that Merleau-Ponty delivered in the late 1950s and early 1960s. These notes shed helpful light on the development of his philosophy_particularly his thinking of the petite phrase of Proust in the second half of the "Chiasm" chapter - and effectively put to rest any temptation we might have to reduce the notion of "flesh" to a naturalistic domain. What Merleau-Ponty's late writings mark out is that, true to his phenomenological roots, he remains, to the end, concerned with investigating the transcendence of the structures of perception; here, however, there is a difference in emphasis, turning from the overflow of the presence of the world to the écart, fissure, or gap pertaining to the structure of time-consciousness. ${ }^{2}$

\footnotetext{
${ }^{2}$ This "gap" does not pertain to the musical experience alone; rather, it is that Merleau-Ponty's philosophical
} 
Emblematic of this turn is a rather enigmatic working note from The Visible and the Invisible dated November, 1960. Titled, "Time and chiasm," Merleau-Ponty writes that we must consider a sense of time in which "past and present are Ineinander, each enveloping-enveloped-and that itself is the flesh" (1968, pp. 267-268). I propose that we adopt this note as our theme, attending closely to this notion of the Ineinander and the way that - thanks to a new engagement with music that emerged at the end of the 1950s - it serves as a complementary notion to the "intertwining" that we so readily associate with the theme of embodiment. We will want to take a closer look at the nature of this chiastic structure, particularly in relation to the Ineinander of past and present that gives us the "flesh."

On the one hand, Merleau-Ponty employs the term Ineinander, in-one-another, when he wishes to rethink what might otherwise be regarded as a dualist pair; for example, he uses the term as a way to reframe the relation between self and other, human and animal, and past and present. In this sense, we could say that Ineinander belongs to a general constellation of metaphors that Merleau-Ponty invokes throughout his later work, like interweaving, intertwining, and encroaching - terms that reintegrate or reimagine oppositional relations. ${ }^{3}$ More pointedly, Ineinander seems to indicate the kind of co-presence or simultaneity that these other terms express. On the other hand, if we look carefully at the contexts within which Merleau-Ponty uses Ineinander, we begin to appreciate the striking way in which the term takes on a certain specificity. That is to say, Ineinander is not just about present relations in space - about the all-at-onceness that bodies sustain. Merleau-Ponty employs it as a means of articulating the temporal and intersubjective dimensions of the flesh.

The term is one that Merleau-Ponty adapts from his reading of Edmund Hussurl, especially Husserl's works like Ideas II, The Crisis of European Sciences and Transcendental Philosophy, and "The Origin of Geometry," where Ineinander appears with some frequency. As it is well known that Merleau-Ponty travelled to Leuven in 1939 to consult these manuscripts in the Husserl Archives, we might have expected the term to show up in MerleauPonty's work as early as Phenomenology of Perception. For in the preface of this work, Merleau-Ponty not only presents a sympathetic reading of Husserlian phenomenology but also makes ready use of Husserlian vocabulary. However, Merleau-Ponty gives no mention of Ineinander here — nor in "Phenomenology and the Sciences of Man," nor "The Philosopher and His Shadow" (essays that also pay homage to Husserl). Although Merleau-Ponty's

\footnotetext{
engagement with the petite phrase of Proust provides a way into the thinking of the écart. The structure of the écart, because it pertains to time-consciousness, characterizes all of perceptual experience (not only music). Cf. Leonard Lawlor: "Below reflection, and as the origin of reflection, is spontaneous self- or auto-experience. For Merleau-Ponty, auto-experience takes place in the sensible itself, or, as Heidegger would say, in Being itself. More importantly, Merleau-Ponty transforms auto-affection into hetero-affection. Auto-experience is never selfadequate; it always contains latency and invisibility" (Lawlor, 2012, p. 142).

${ }^{3}$ Cf. Leonard Lawlor's analysis of this intertwining or encroachment "between man, world, and writing" in the preface to Husserl at the Limits of Phenomenology (Lawlor in Merleau-Ponty, 2002, p. x). Lawlor's investigation, with respect to its emphasis on writing, provides an interesting complement to the way that I pick up this thread with respect to painting and music.
} 
philosophical work is saturated by his continuous reading and reassessment of Husserlian phenomenology, we might say that, in general, Husserl's term Ineinander functions operatively rather than explicitly in Merleau-Ponty's work; seldom is it brought into the printed publications that Merleau-Ponty produced during his own lifetime. To understand the significance of the term, we must look, rather, to course notes (principally "Philosophie aujourd'hui" and those notes translated as Husserl at the Limits of Phenomenology) and working notes (of The Visible and the Invisible). ${ }^{4}$ Through careful attention to these notes, we might see that the term arguably stands beneath the development of the whole of Merleau-Ponty's late philosophical project. For in a draft of The Visible and the Invisible dated October 1960 - a draft published as an annex to the Notes de cours (1959-1961) - MerleauPonty claims, evocatively, "Philosophy is, as method, knowledge of the Ineinander" (1996, p. 366). Thus, we should attend carefully to what this Ineinander articulates.

Merleau-Ponty's most sustained engagement with the term is to be appreciated in notes to the course given at the Collège de France in 1958-1959 called "Philosophie aujourd'hui." The course calls for a reassessment of Husserl and Heidegger, and as preface to this exploration Merleau-Ponty presents his own examination of contemporary philosophy by turning to literature, painting, and psychoanalysis. Following an impassioned investigation of the art of painting - the sense of which comes to full expression later in his essay, "Eye and Mind"- - he composes a few sheets of paper dedicated to music, and it is here, in a footnote, that our term first appears: as the "Ineinander me-world" relation (1996, p. 65).

\footnotetext{
${ }^{4}$ Following the course "Philosophie aujourd'hui" of 1958-1959, Merleau-Ponty's course of 1959-1960, "Nature and Logos: The Human Body," employs the term Ineinander to describe the way that our humanity is interwoven with the animal world, writing that "the human [is] to be taken in the Ineinander with animality and Nature" (2003, p. 208). Although, on first glance, we might take this Ineinander as a relation between things (e.g. animalhuman bodies), Merleau-Ponty challenges any naturalism that would make of it only a relation of objects in space; on the contrary, he writes that "the concern is to grasp humanity [...] not as another substance, but as interbeing," or, as he says a bit later, as "an Einfühlung with the world" (2003, p. 209). This world is not simply a world of objects within space but is a cultural world - a world that therefore encompasses the horizon of the past. (See also the working note dated February 1959 from The Visible and the Invisible, 1968, p. 172.) Here, again, Ineinander and Einfühlung are linked, and it is fitting that the notes on Nature present a compelling gesture toward an analysis of melodic succession: "The melody gives us a particular consciousness of time. We think naturally that the past secretes the future ahead of it. But this notion of time is refuted by the melody. At the moment when the melody begins, the last note is there, in its own manner. In a melody, a reciprocal influence between the first and the last note takes place, and we have to say that the first note is possible only because of the last, and vice versa" (2003, p. 174). For extensive analyses of the role of the musical melody as a metaphor in Merleau-Ponty's Nature lectures, see Mauro Carbone's essay, "Nature: Variations on the Theme" (Carbone 2004) and Ted Toadvine's article, "The Melody of Life and the Motif of Philosophy" (Toadvine 2005).

The notion of Ineinander also plays a role in both courses of 1960-1961, "Philosophie et non-philosophie depuis Hegel" and "L'ontologie cartésienne et l'ontologie d'aujourd'hui." In the latter course, it appears in an analysis of movement in sculpture (Rodin) and painting (Géricault) as the Ineinander of "space-time" (1996, p. 172); yet it is interesting to note that in the passage of "Eye and Mind" (1993, p. 145) that directly corresponds to these course notes, the term Ineinander is not used. "Eye and Mind," as I have tried to show, above, focuses more on the embodied aspects of perception than the movement of transcendental subjectivity, which Merleau-Ponty associates most directly with the petite phrase of Proust.
} 
In this context, we might be tempted to understand Ineinander primarily as a spatial relation ("me" in the corporeal sense and "world" as an array of things), but Merleau-Ponty makes it clear (through the use of the term Entfaltung or unfolding) that the Ineinander here has to do with the movement of music in time. And it is this temporal element that might explain why an important term such as Ineinander makes its appearance here in a small and often overlooked passage on music — music as an expressive art of time.

For the expression of the musical melody had also served as a principle example in Husserl's own phenomenological reflections upon the structure of time-consciousness. ${ }^{5}$ Toward the beginning of On the Phenomenology of the Consciousness of Internal Time (1893-1917), Husserl writes:

When a melody sounds, for example, the individual tone does not utterly disappear with the cessation of the stimulus or of the neural movement it excites. When the new tone is sounding, the preceding tone has not disappeared without leaving a trace. If it had, we would be quite incapable of noticing the relations among the successive tones; in each moment we would have a tone, or perhaps an empty pause in the interval between the sounding of two notes, but never the representation of a melody. On the other hand, the abiding of the tonerepresentations in consciousness does not settle the matter. If they were to remain unmodified, then instead of a melody we would have a chord of simultaneous tones, or rather a disharmonious tangle of sound, as if we had struck simultaneously all the notes that had previously sounded. (Husserl, 1991, p. 11)

The challenge presented by the melody is the challenge of understanding succession - that is to say, how each moment of the "now" does not pass away to oblivion, nor is it held or sustained as a sensation of the present (i.e. through temporal modifications). The movement of succession - as in the flowing expression of a melody - can be perceived only, as Aristotle has shown us, as the actuality of potentiality, e.g. the potential or absent pastHusserl's retention - and the potential or non-present future-Husserl's protention. Therefore, the structure of time-consciousness must somehow take into account, in Merleau-Ponty's words, "a past that is present to us only through the determinate void that it leaves in us" (1970, pp. 50-51).

Husserl's own solution to this challenge - as he works it out through the phenomenological investigation known as No. 50 in Husserliana X-is the double intentionality of retention, a double structure (or, we could perhaps say, a chiastic structure) pertaining, on the one hand, to the constitution of the world (i.e. objectivity) and, on the other hand, to the constitution of the self (i.e. transcendental subjectivity). What is important to underline is that, for Husserl, these two intentionalities are not separate ways of understanding our perception of something like a melody, but two non-independent parts of a unitary whole known as consciousness. That is to say, both intentionalities are necessary. In particular, phenomenology's task seems often to have been to insist upon the latter intentionality, for

\footnotetext{
${ }^{5} \mathrm{Cf}$. also Derrida: "The sonorous source attempts to rejoin itself only by differentiating itself, dividing, differing, deferring without end [...] The source therefore is not the origin, it is neither at the departure or the arrival" (Derrida, 1982, p. 287).
} 
it is the flowing, ever-the-same-and-ever-new movement of the subject that too often has been overlooked in studies that would seek out a so-called objective structure of time. On the contrary, it is the movement of what Husserl terms absolute subjectivity - a movement that, as a flowing, is perceived more through absence than presence to itself - that makes possible the perception of a melody.

Therefore, when Merleau-Ponty writes, in that famously enigmatic working note of The Visible and the Invisible, that "past and present are Ineinander" (1968, p. 268), he does not mean that the past is simultaneous with the present - in other words, he does not mean that the past would be reducible to a present sensation; he means, rather, that through the succession or the flowing of present to past in the experience of the subject, the past is "in" the present as retention — as the sense of absence, of pastness (i.e. empty of content) and the present is "in" the past as protention-as the sense of a not-yet (i.e. also empty of content). Thus, in contrast to Phenomenology of Perception, where Merleau-Ponty writes that, "My body takes possession of time; it brings into existence a past and a future for a present" (1981, p. 279), in The Visible and the Invisible, we must think of time not as a possession of the body but as a "difference" or a "transcendence" (1968, p. 195). MerleauPonty writes, "The transcendence of the present makes it precisely able to connect up with a past and a future" (1968, p. 196). For this is what characterizes the particular temporal structure that pertains to transcendental subjectivity: it constitutes its sense-its unitythrough its dynamic movement that always slips away. This anticipates Merleau-Ponty's description of the petite phrase of Proust:

With the first vision, the first contact, the first pleasure, there is initiation, that is, not the positing of a content, but the opening of a dimension that can never again be closed, the establishment of a level in terms of which every other experience will henceforth be situated. (1968, p. 150)

Thus, Merleau-Ponty's invocation of the term Ineinander within the context of an investigation of the flowing of music sets the stage in the notes to "Philosophie aujourd'hui" for the extended analysis that follows (see pages 79-90 of the Notes de cours). In this discussion, Merleau-Ponty employs the term not only with respect to temporality (as the "Ineinander of the present and of the past," Merleau-Ponty, 1996, p. 83) but also with respect to what he terms the "pre-theoretical Einfühlung" or the empathy that characterizes "transcendental intersubjectivity" (1996, p. 79). It is this critical linkage - between the Ineinander of time-consciousness and the Ineinander of transcendental intersubjectivity - that hints at the term's potential to illuminate the key role played by Husserl's work in Merleau-Ponty's own development of the notion of flesh. For the flesh is not the body: "the flesh we are speaking of is not matter" (1968, p. 146). The flesh emerges, rather, at the exchange - the intercourse - between the configurations of the sensuous realm and the flowing subject who transcends what is merely present. Here, within the dimension of the self who, in her flowing, always just misses herself (thereby performing the condition of possibility for an other - an other subject - to appear), lies the heart of intersubjectivity. Indeed, this is why, for Merleau-Ponty, transcendental subjectivity is already a "transcendental intersubjectivity" (1996, p. 79). As the direction of the course, "Philosophie aujourd'hui," leads from 
Husserl to Heidegger (and Merleau-Ponty drops most of Husserl's vocabulary for that of Heidegger), nevertheless this link between the Ineinander of temporality and that of empathy returns, significantly, at the penultimate sentence of the course notes, where MerleauPonty compares Heidegger's "advent of being" with Husserl's notions of "Ineinander and Einfühlung" (1996, p. 148). Here, the "and" must be emphasized, for it is the very linking of Ineinander and Einfühlung (as empathy) that seems to offer Merleau-Ponty a way out of a philosophy of the body and toward a philosophy of the flesh and what he terms (in draft outlines from March 1959 and May 1960) the "inter-world" (1968, p. xxxv).

It is no wonder, then, that during the academic year of 1958-1959, we see the term Ineinander appear in the working notes of The Visible and the Invisible (for example, 1968, pp. 172, 174, 180). And in the following academic year (1959-1960), when MerleauPonty delivers a course known as Husserl at the Limits of Phenomenology, he continues to emphasize the Ineinander of temporality and the Ineinander of transcendental intersubjectivity (for example, 2002, pp. 16, 20, 29, 47, 50, 53, 58, 76). This is also reflected in the working notes to The Visible and the Invisible dating from April of 1960, where Merleau-Ponty mentions Ineinander in explorations of time-consciousness and empathy (see, for example, 1968, pp. 204, 244, 245).

Hence, we see the influence of this new way of thinking about the movement of music in the actual text drafted as the final chapter of The Visible and the Invisible, "The Intertwining-The Chiasm." While the "intertwining" in the title thematizes a structure of embodiment long developed throughout Merleau-Ponty's oeuvre, the "chiasm" points to the necessity of taking into account that other dimension at work in the flesh - that of transcendental intersubjectivity. Contrary to the overflowing presence experienced by the body in the world, this is a structure characterized by absence - by succession - by the écart. It is constituted as "a certain hollow, a certain interior, a certain absence, a negativity that is not nothing" (1968, p. 151), and it finds, for Merleau-Ponty, its most natural expression in the movement of music. Hence, he turns to the petite phrase of Proust in the final passages of the "Chiasm" chapter. Contrary to the claim he had made in Phenomenology of Perception that in music, "the meaning appears as linked to the empirical presence of the sounds" (1981, p. 219, emphasis mine), here in The Visible and the Invisible he writes, "We do not see, do not hear" the musical idea, "not even with the mind's eye" (1968, p. 151). The sense of the music, he continues, is "behind the sounds or between them" (1968, p. 151). Indeed, we could not grasp the sense of this music all at once or make it present. "Each time we want to get at it immediately," Merleau-Ponty writes, "or lay hands on it, or circumscribe it, or see it unveiled, we do in fact feel that the attempt is misconceived, that it retreats in the measure that we approach" $(1968$, p. 150). It is its movement - its transcendence - that constitutes its power of intersubjective expression, for it is "communicable to all who hear it" (1968, p. 149).

And this is how the musical experience comes to assume significance for Merleau-Ponty. Certainly, it is not the case that, in the final passages of the "Chiasm" chapter MerleauPonty executes a metaphorical about-face and rejects the notion of embodiment together 
with the significant role that it must play for philosophy. After all, when Merleau-Ponty writes that musical ideas "give us the assurance that the 'great unpenetrated and discouraging night of our soul' is not empty, is not 'nothingness'," he adds: "but these entities, these domains, these worlds that line it, people it, and whose presence it feels like the presence of someone in the dark, have been acquired only through its commerce with the visible, to which they remain attached" (1968, p. 150). What Merleau-Ponty develops in these passages is a chiastic structure that accommodates both the simultaneity (guaranteed by the body) and the succession (as flowing non-presence) of time. To illuminate the former, he engages with painting, but as inspiration for the latter, he turns to music. But the two, in their differentiation, constitute non-independent parts of a whole structure: a philosophy of the flesh. Here, through the flesh, there is a "cohesion of space; cohesion of time," Merleau-Ponty writes in the section of notes to "L'ontologie cartésienne et l'ontologie d'aujourd'hui" that precisely follow his analysis of the musical idea of Proust, "but cohesion that is not indistinction, that is of the incompossibles, that is encroachment, absence" (1996, p. 199). Accordingly, as we witness in the "Chiasm" chapter, Merleau-Ponty expands his thinking from the fecundity of presence (and "encroachment") to the creative possibilities of transcendence (and "absence").

Therefore, his claim, in Phenomenology of Perception, that, "True philosophy consists in relearning to look at the world" (1981, p. xxiii), must be tempered with his later assertion, in one draft of The Visible and the Invisible, that, "Philosophy is, as method, knowledge of the Ineinander" (1996, p. 366). The flesh expresses not only the immersion of a body in the world that sees; it expresses also, as that which is no longer and that which is to come, a creative movement of time. We who adapt Merleau-Ponty's work in the presentday must be mindful, therefore, not to reduce his philosophy to a set of doctrines about embodiment or painting. We must take into account both dimensions of his chiastic structure - that of the intertwining of vision and visibility as well as the Ineinander of past and present - if we are to uphold the promise of his philosophy of the flesh.

\section{References}

Carbone, M. (2004). The Thinking of the Sensible: Merleau-Ponty's A-Philosophy. Evanston, IL: Northwestern University Press.

Claudel, P. (1948). Poetic Art. (R. Spodheim, Trans.). New York, NY: Philosophical Library.

Derrida, J. (1982). Margins of Philosophy. (A. Bass, Trans.) Chicago: University of Chicago Press.

Husserl, E. (1991). On the Phenomenology of the Consciousness of Internal Time (1893-1917). (J. Brough, Trans.). Dordrecht, the Netherlands: Kluwer.

Lawlor, L. (2012). Early Twentieth-Century Continental Philosophy. Bloomington: Indiana University Press.

Merleau-Ponty, M. (2008). The World of Perception. (O. Davis, Trans.). London, UK: Routledge. 
Merleau-Ponty, M. (2003).. Nature: Course Notes from the Collège de France. (R. Vallier, Trans.). Evanston, IL: Northwestern University Press.

Merleau-Ponty, M. (2002). Husserl at the Limits of Phenomenology. (L. Lawlor, Trans.) Evanston, IL: Northwestern University Press.

Merleau-Ponty, M. (1996). Notes de cours au Collège de France, 1958-1959 et 1960-1961. (S. Ménasé, Ed.). Paris, France: Éditions Gallimard.

Merleau-Ponty, M. (1993). Eye and Mind. In G. Johnson (Ed.), The Merleau-Ponty Aesthetics Reader: Philosophy and Painting (pp. 121-150). Evanston, IL: Northwestern University Press.

Merleau-Ponty, M. (1981). Phenomenology of Perception. (C. Smith, Trans.). London, UK: Routledge.

Merleau-Ponty, M. (1970). Themes from the Lectures at the Collège de France, 1952-1960. (J. O’Neill, Ed.). Evanston, IL: Northwestern University Press.

Merleau-Ponty, M. (1968). The Visible and the Invisible. (A. Lingis, Trans.). Evanston, IL: Northwestern University Press.

Proust, M. (1981). Remembrance of Things Past. (Vol. 3, C. K. Scott Moncrieff, T. Kilmartin, \& A. Mayor, Trans.). New York, NY: Vintage Books.

Toadvine, T. (2005). The Melody of Life and the Motif of Philosophy. Chiasmi International, 7 , 263-278.

Wiskus, J. (2013). The Rhythm of Thought: Art, Literature, and Music after Merleau-Ponty. Chicago, IL: University of Chicago Press. 